\title{
MEDIA AND SPACE DISCLOSURES OF THE POWER COURT
}

\author{
Oleh: \\ Ce vi Mochamad Taufik ${ }^{1}$
}

\begin{abstract}
The era of the third wave of media can reveal the dark dimensions of power. Private spaces that are hidden behind arrogant individuals are drawn into public spaces to become important topics. There is no secret other than the spread of issues on various media platforms. Various coverage from personal dimensions to policy areas is clearly revealed. Furthermore, to find out the background behind it, this study uses descriptive qualitative methods with the aim of obtaining data in order to explain the phenomena which is the theme of this research. From the results of the research analysis shows that the media are able to reveal dark spaces of power to the ability to eliminate practices that occur in them.
\end{abstract}

\begin{abstract}
ABSTRAK
Era media gelombang ketiga dapat mengungkap dimensi gelap kekuasaan. Ruang-r uang private yang tersembunyi di balik pribadi-pribadi angkuh ditarik ke ruang publik hingga menjadi topik penting. Tidak ada lagi rahasia selain tebaran isu di berbagai palform media. Berbagai liputan yang berdimensi pribadi sampai pada wilayah kebijakan diungkap dengan jelas. Selanjutnya, untuk mengetahui latar di balik itu, penelitian ini menggunakan metode kualitatif deskriptif dengan tujuan mendapatkan data agar dapat menerangkan fenonema yang menjadi tema penelitian ini. Dari hasil analisis peneltian menunjukkan bahwa media mampu mengungkap ruang-ruang gelap kekuasaan sampai pada kemampuan melenyapkan ptaktik-praktik yang terjadi di dalamna.
\end{abstract}

${ }^{1}$ Universitas Kebangsaan Republik Indonesia, Prodi Ilmu Komunikasi. Bandung, Jh. Terusan Halimun No. 37 Bandung, Jawa Barat. Email: cevimtaufik@gmail.com

Program Studi Ilmu Komunikasi - Institut Bisnis dan Informatika Kwik Kian Gie 


\section{INTRODUCTION}

Long before the era of media convergence, power tended to conspire with elements of the media. Various cases surrounding the ruler have been negotiated so that they are not exposed to the surface. The description of all the events that occurred, is constructed in a safe atmosphere and does not disturb peace. In other words, the media did not present the case that was successfully negotiated to the public space, but kept it in a dark space which was preserved for further purposes. However, this is only a small illustration of the case of the mass media administration system that deviates from the provisions.

This also confirms that although the competency standard is a reference in the behavior of media personnel, in practice it is not free from acts of violations and fraud. Especially when it comes to power. In addition to inherent in the media the power to shape public opinion, it is also the power that is manifest in instruments symbolized by state administrators. Relationships that occur in formal spaces, as a form of implementation of duties as information packers and their partners are state officials. The relationship that occurs will also take place in an informal space that shows the proximity of the media to the mirror. The power that is exchanged will produce a double-dimensional effect in the form of a positive effect and a negative effect.

The positive effect will be in the form of an image enhancement of the administrators of power, which is described as flawless. In a section like this, the public believes that the critical value of the media will be blunt. The tasks assigned to provide facts and truths objectively replaced with subjective elements that were packaged according to their own interpretation of power. Meanwhile, on a negative effect, the public will perceive that the media are playing their role as information givers by accentuating their critical values.

However, in practice, the effects that arise are not permanent. At certain times, the media will have a negative effect on the creation of relations with power and at other times will have a positive effect on relations. Both of these effects become risks in carrying out the task of controlling public opinion. The ability to manage these effects works in harmony with situations and conditions.

In the situation and conditions of the capitalist system the media as part of it, of course, must be able to regulate the rhythm so that it can operate and be in line with the current system However, if they reject the capitalist system the media will certainly face the rulers who are convincingly able to undermine the values of idealism and even later on, the power in this form of capitalism begins to dominate and become the owner of the media.

Thus, the idealism which is the basis of media values fades along with the operationalization of the media in changing its business form The level of resilience and

longevity of media is determined based on its ability to balance idealism with business. Although the value is opposite, in practice it can produce stone values that are in accordance with current conditions. The relation between media and power sammai on the disclosure of the dark space created can be illustrated in the following picture: 


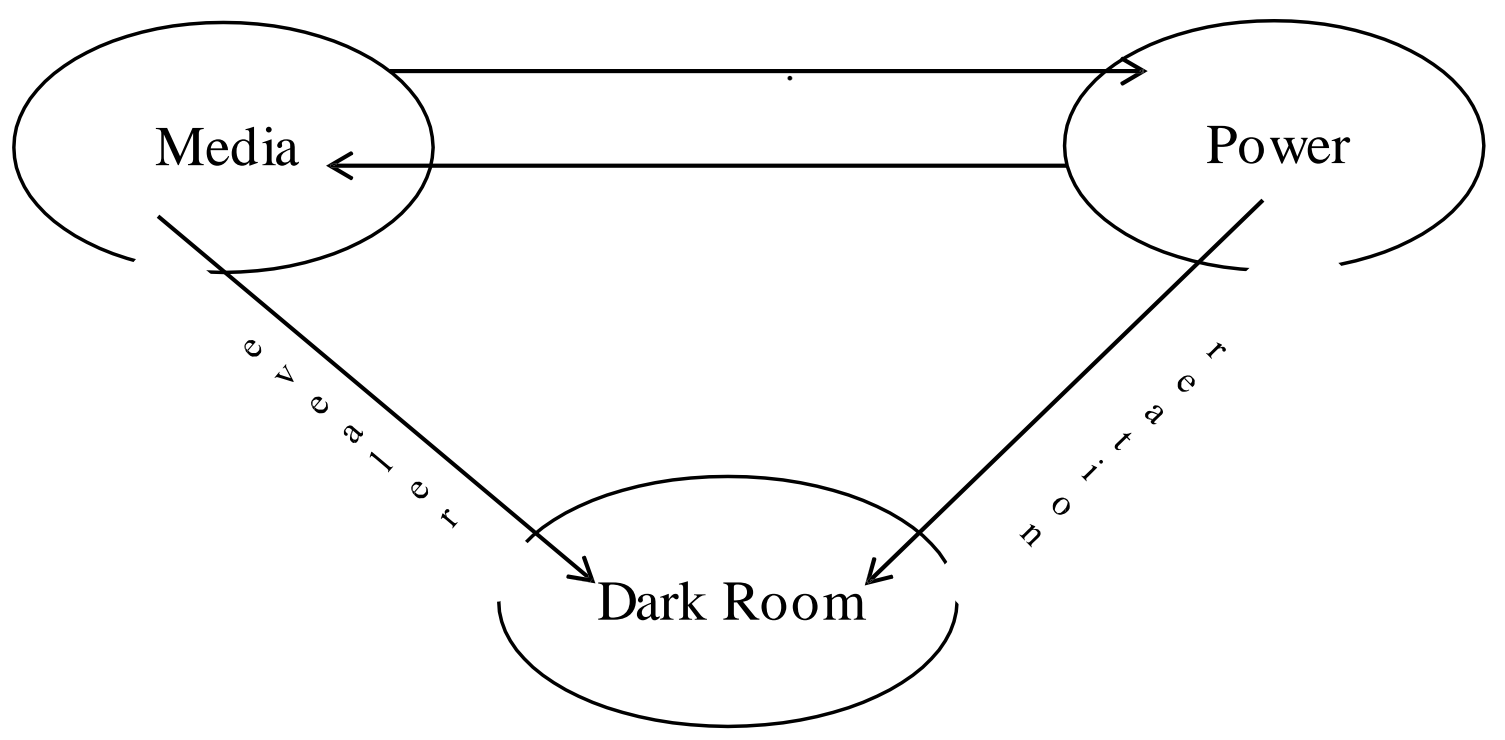

Figure 1

Media relations with power

Based on this picture, it shows that the relationship that occurs between the media and power goes both ways with the result of the creation of dark spaces. The initiative of the existence of darkroom space can come as an offer given to power, while the media only acts as the party that can agree on the offer. The media can also refuse the dark room by disclosing it.

The reasons for the disclosure depend on the good or bad situation of the relationship that is created. Kindness and disrespect are effects which can have certain consequences. As with the relationship that has occurred, the image shows media practice which is the result of interpretation of the space.

Unlike the case with digital media, which in the development of media belongs to the era of the third wave, blurry portraits of power are clearly displayed. The disclosers are citizens who are not registered as members of the community affiliated to certain power and media offices, but only represent individual aspirations.

The results of his coverage lead to situations that can illuminate the dark spaces of power that have been stored in public knowledge. Power that is too repressive, for example, is presented with a very bombastic news headline and tinged with subjective elements with the aim of directing public opinion to the construction it does. Likewise, his comments on the patronizing of power with his corrupt partners did not escape. Other coverage on the economy, politics, law, to the actual condition of society does not escape from its coverage efforts. 
The information processing mechanism is simple and independent in nature. Unlike what happens in conventional media, in this era of media convergence, it is possible for every individual who has an account on social media to process news of events without paying attention to ethics and the impact it causes. Only by using a gadget or device in his hand every scene from the events that occur around him are clearly recorded. Social media spaces also tend to be full of various displays of violence, sadism, pornography, or corrupt views of the apparatus of state institutions.

This massive development of social media content is seen to be at an alarming level. The moral foundation that guides media behavior is not a reference. What appears is that personal interests are more dominant than carrying out the ideals adopted by conventional media actors who are oriented towards public interests. However, the announcement of this event is understandable considering the condition of social media activists who do not have journalistic competence. Meanwhile, this competency is an obsession held by media regulators with the aim that all journalists in this country have competence in carrying out their duties.

At a higher level, the regulator of the information circulation system leaves the settlement mechanism to legal instruments, as it demands the public to have intelligence in interacting with the media, especially in the section regarding information management. Media spaces are too wide to be observed, so that only certain parts, especially those suspected of being the cause of division and potential betrayal of the state, receive very serious attention.

The objective condition of the media with all its behavior covers all aspects of life. From those that are secret in nature to affirmations in cases that are already bright. The various perspectives used describe the shedding of hidden thoughts. Likewise with the ability to spread from one device to the next device or from one account to another, causing a certain thought to be considered the same thought that is generally recognized. This can be understood when referring to $\mathrm{Mc}$ Luhan's statement which states that the media has played a role as an extension of the human mind (Littlejohn \& Foss, 2011: 411).

From that viewpoint, it can be explained that the media, one of which is about the mind. If a thought about the exercise and administration of power is diverted by certain individuals, then by using the facilities available in social media as a viral means, it will become a portrait that shows a real picture of power. Thoughts as opposed to the act of power lead to a form of expression. The atmosphere will be different when the results of the exposure are shared through the media. In other forms, this power will be interpreted negatively. Because of the position

\section{RESEARCH METHOD}

This study intends to seek a complete explanation of the phenomenon of disclosure regarding dark spaces that allegedly occurs in government agencies and institutions as part of the relationship between media and power. The explanation of this phenomenon is based on descriptive qualitative methods which aim to obtain the data obtained. Disclosure of these data is obtained either through documents that become public records or through direct observation of the events behind the phenomena that are the object of research.

\section{RESULTS AND DISCUSSION}

The mass media have a central position. This is evident from its function which consists of providing information to 
the public, educating and entertaining. Thus, the definition of media is an intermediary or means used by the masses in relation to one another. Likewise, Harold D Laswell, who mentioned three functions of media, including: to inform or provide information, to educate or educate functions, and to entertain or provide entertainment. Lasswell's statement shows the real function of the mass media.

In practice, people not only see the media as conveying information, but many are enlightened by information that is educational. On the other hand, many people place the media as a means of getting entertainment. This is stated in the form of colums and pages in print media that display information regarding these three functions. However, another expert, Chalres Wright, does not only look at these three functions but more broadly by mentioning the functions of the mass media as follows:

1. Surveillance, carried out on a variety of events carried out through a process of reporting and reporting with various impacts.

2. Correlation, this means that the mass media mobilizes the masses to think and behave on an event or problem

3. Cultural Transmission, that is, it functi ons as cultural inheritance and socialization.

4. Entertainment, namely the mass media functions to provide entertainment to the community.

Based on the views of Wright and Laswell, there are functions between entertainment. This was also stated by Josep A. De Vito who explained the function of the mass media as follows:

1. Entertaining

2. Convincing

3. Inform

4. Confer status

5. Sedate

6. creates a sense of oneness
From the point of view of the three communication experts it is clear that the media perform the same function and hit society with a variety of unattainable goals. In one of its functions, namely: entertaining, the goal to be achieved is to provide a channel for the community to get out of certain situations that are considered unfavorable. To strengthen the views of the three communication experts, the Press Law No. 40 of 1999 also provides an explanation of the function of the mass media as follows:

1. To Inform

2. To Educate

3. To Entertaint

4. Social Control

All functions attached to the media have been carried out in accordance with the procedures governing it. In the educational function, the media is tasked with enlightening the public's mind from the possibility of being confused with wrong information. Likewise in carrying out the function of informing and entertaining has become the most important part. Only in its function as social guardian, media has a different attitude. Some even try to blunt this function because the media has the status of a partisan media whose job it is to support and support any decisions issued by the authorities.

However, the control used is focused on the opposition which puts itself in the face of power. It is this media movement that allows the creation of dark spaces as a form of unwritten agreement. However, the agreement is not permanent, can change at any time if the political direction of the media owners changes and leads to a policy of dealing with power.

In the relationship that occurs, politics mediates the relationship between the two entities. In fact, power is part of the study of political science. This is as emphasized by political experts as quoted by Budiadjo, 
(2008: 18), experts who emphasize power as the core of politics think that politics is all activities related to the problem of fighting over and maintaining power. It is usually considered that this power struggle has an objective that concerns the interests of the whole society. Budiardjo also quoted Lasswel's statement as saying that political science studies the formation and distribution of power.

To strengthen this view, WA Robson is still in Budiardjo explaining that political science studies power in society, namely the nature, essence, basis, processes, scope and results. The focus of attention of political scholars is on the struggle to achieve and maintain, exercise power, or influence over others, or oppose the exercise of that power.

From this statement, it shows that the relationship that occurs between the media and power comes from political relations. Power that tends to corrupt, as said by the British nobleman, Lord Acton, needs a partner who can keep the corruption of his power from being exposed to the surface. History records that the overthrow of a regime, one of which originated from the disclosure of corruption of power through the media, which ultimately led the public to take actions against the exercise of this deviant power.

Disclosure of the dark space of power concerns all aspects of life. This is in line with the role of the media as stated by McQuaill (1987) that mass media has a certain role in serving the public's curiosity. According to McQuail, a number of roles have been played by the mass media so far, namely:

1. Industries that create jobs, goods, and services as well as revive other industries, especially in advertising / promotion.

2. Sources of power - tools of community control, management, and innovation.

3. Location (forum) to display community events.
4. A vehicle for cultural development procedures, fashions, lifestyles, and norms.

5. The dominant source of creating images of individuals, groups and society.

In the period of conventional media civilization, disclosure efforts were carried out ethically based on predetermined rules and coverage standards. The media do not dare to deviate considering the consequences it can receive and the risks that will occur to the media and its reporting team The media also counts that if they reveal the dark spaces of power in an authoritarian government system, it can have fatal consequences.

However, in an atmosphere of a democratic justice system the media have obligations and are often tempted to present even sensitive events. The democratization of media with the essence of press freedom finds its partners in social media spaces. With each other, synergize to complement each other. Both play a role in making the atmosphere more transparent. The dark spaces of power disappear by themselves. Individuals who always act arbitrarily can no longer act freely. The tight controls exercised through the handheld devices directly record the actions and actions that lead to the abuse of power. Without going through the process of editing and censoring the captured scenes, the result is wild and spread across all channels ow ned by the public. The ability of social media with its viral facilities on the one hand is a source of inspiration for conventional media coverage.

The accelerated role between the two media raises opinions in the community with the understanding that the information disseminated by social media has no validity if it has not been published in the mainstr eam media. However, with the development of online-based media platforms, it actually creates media spaces that have verified new 
value. This can be proven by the convenience provided by a certain application system, which allows everyone who has scientific capacity or who does not have a scientific basis to create their own free media in blog format. Likewise with the convergence path of unifying various media platforms into a means of information packaged in the form of a website.
Democratization, which makes all aspects of life very transparent, encourages the media operating system to develop in creating the media environment itself. Various coverage of various events that occur becomes a powerful control tool to avoid behavior that deviates from the provisions. To explain this situation, it can be described as follows:

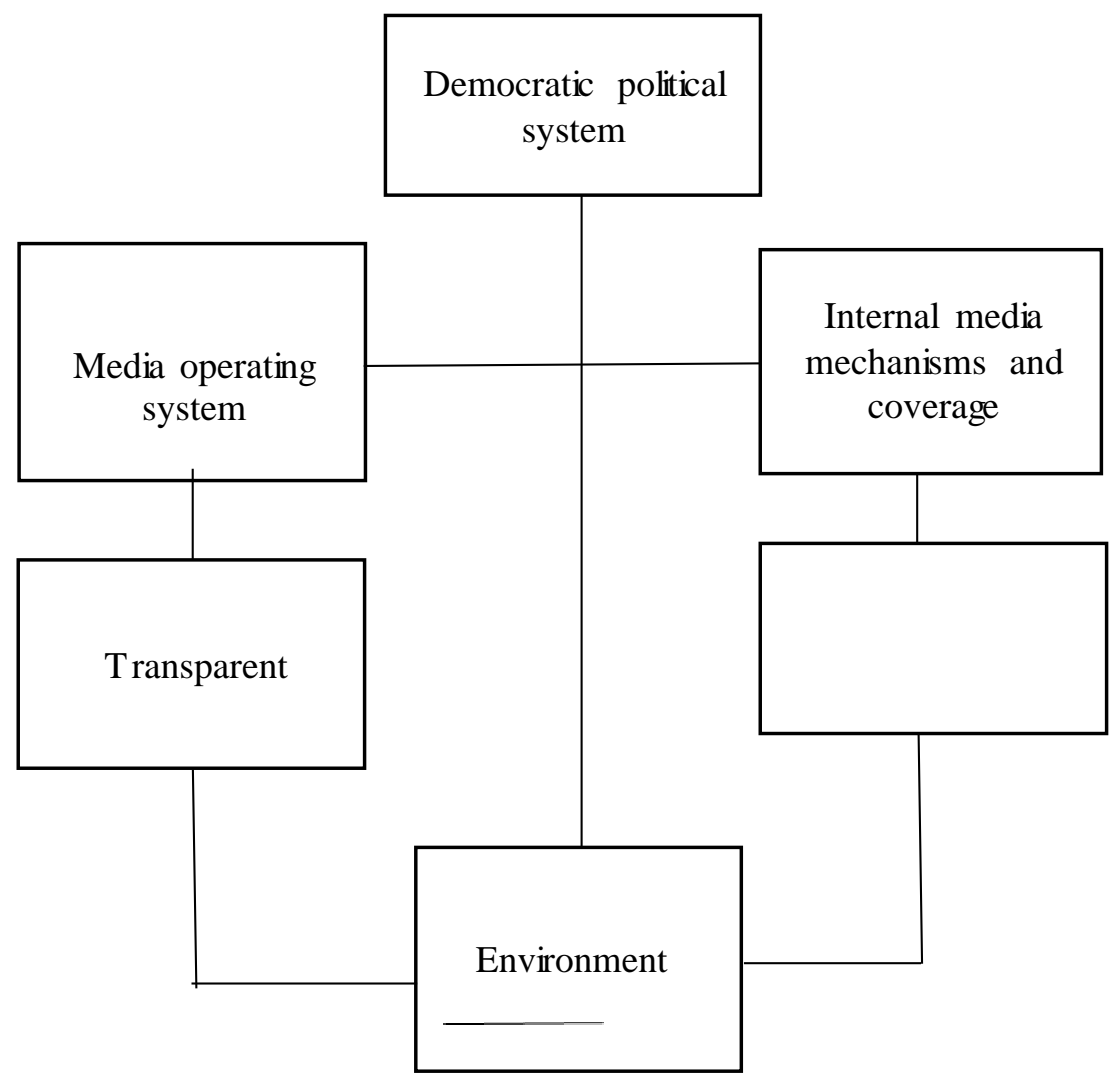

Figure 2:

Media Systems Create Environments 
Based on the figure, it shows that the media operating system runs in a political system Its various coverage follows the policies applied in a democratic system, which allows the emergence of various transparencies that open up all spaces of life. These transparent values are conditioned into media rituals that become habits which in tur $n$ become tools to control behavior.

\section{REFERENCES}

Assegaf, Djafar H, 1991, Jurnalistik Masa Kini, Jakarta Ghalia Indonesia. Pustaka Littlejhon, Stephen W, Foss, Karen A, 2009, Teori Komunikasi, Theories of Human Communication, Jakarta, Salemba Humanika.

McQuail, Denis, 1987, Mass Communication Theory (Teori Komunikasi Massa), Jakarta, Erlangga,

Nurudin, Komunikasi Massa, CESPUR, Malang, September 2003.

VIVA. 2018. Blued, Aplikasi Pecinta Sesama Jenis dengan 27 Juta Pengguna, (Online),

(https://ww w.viva.co.id/arsip/996784blued-aplikasi-pecinta-sesama-jenisdengan-27-juta-pengguna. Diakses 9 November 2019).

William R. Rivers at.al., Media Massa dan Masyarakat Modern: Edisi Kedua, Prenada Media, Jakarta, 2003.

Woodward, Kathryn (ed.). 2002. Identity and

Difference. London: SAGE Publications.

Yulius, Hendri. 2019. C*BUL: Perbincangan Serius tentang Seksualitas Kontemporer. Tangerang Selatan: Marjin Kiri. 